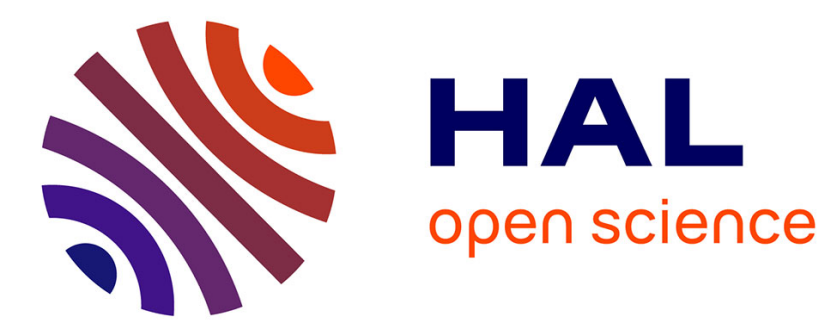

\title{
Cultural heritages: From official to informal
}

Christian Barrère

\section{To cite this version:}

Christian Barrère. Cultural heritages: From official to informal. City, Culture and Society, 2016, 10.1016/j.ccs.2015.11.004 . hal-02569029

\section{HAL Id: hal-02569029 \\ https://hal.science/hal-02569029}

Submitted on 10 May 2020

HAL is a multi-disciplinary open access archive for the deposit and dissemination of scientific research documents, whether they are published or not. The documents may come from teaching and research institutions in France or abroad, or from public or private research centers.
L'archive ouverte pluridisciplinaire HAL, est destinée au dépôt et à la diffusion de documents scientifiques de niveau recherche, publiés ou non, émanant des établissements d'enseignement et de recherche français ou étrangers, des laboratoires publics ou privés. 


\section{Christian Barrère}

Université de Reims Champagne Ardenne

\section{Cultural heritages: From official to informal}

in

\section{City, Culture and Society, vol. 7, Issue 2, pp. 87-94.}

DOI: 10.1016/j.ccs.2015.11.004 


\title{
Cultural Heritages: From Official to Informal
}

\begin{abstract}
International organizations define and legitimate 'official' heritages. Yet a heritage policy must go beyond the definition and management of a list of elements belonging to a given heritage. Informal, non-official heritages (from handicraft traditions and recipes, to languages) play a growing role in both the working of modern economies and the quality of social life. To build an economic analysis of informal heritages, we propose reaching beyond the pro-officialheritage bias of the standard economic analysis by widening the notion of heritages on the basis of specific economic and sociological analyses. Next, we apply this broadening to the study of the informal heritages' consequences on both the economy and social life. We conclude that, since informal heritages are at work in the economy and in social life as much as - and even more than - formal heritages, it is high time we extended economic analysis to these new fields and came up with new ways of managing informal heritages!
\end{abstract}

Key words: Heritages, Cultural Heritages, Property Rights.

\section{INTRODUCTION: THE NEW CHALLENGES OF HERITAGE ANALYSIS}

Cultural economics attempts to accord culture its rightful place. This implies consideration the time and space context of culture, and more specifically, of present cultural heritages that have a strong influence on economic choices and performances, as well as on the quality of social life. Culture matters, yes - but what matters even more is culture that has stood the test of time, making the transition to heritage status.

Increasingly, informal heritages are being considered within the numerous existing heritages. Informal heritages are those not included in an institutional process of definition, delimitation and legitimation, as are many local traditions, routines and know-how that have been developed by particular companies and sectors. Today, analyses and policies concerning heritages can no longer be confined to official, formal and well-defined heritages. We think the moment has come to take up this new challenge. In this paper, then, we suggest widening the scope of cultural heritage analysis in two directions: to encompass not just public, but also private (and often productive) heritages, which generally remain informal, as well as social and collective heritages, which are too informal as in the case of languages.

The economic stakes involved in informal heritages are huge. On the one hand, in terms of economic analysis, informal heritages challenge the way in which economics has traditionally considered the relationship between past and present. Economic analysis must evolve by accepting the observation that culture passing through time has very diverse and complex economic and social consequences (Rizzo and Mignosa, 2013). Whereas economists usually reduce heritages to their capital aspects (standard capital for equipment, human and social capital, natural capital and cultural capital) we consider the components of heritages to carry different, and generally intertwined, dimensions - which prevent abstraction of the noneconomic dimensions of heritages when analysing their economic dimension. This interdependence often leads to their being managed through both market and non-market relations, procedures and institutions. Given that the processes of building, transmission and management of heritages depend strongly on their content, their use-value, it is no longer 
possible to analyse these through the unique prism of capital, which summarizes and compresses the past into a value capable of producing new value in the present.

On the other hand, the analysis of informal heritages calls public policy into question, raising very difficult problems for their management: many groups and communities demand protection and fair management of collective and informal resources - be they cultural, social or economic - arising out of the past. However, such claims may be in opposition to the claims of others; just think of the problem of using and sharing water in some areas of the world, or the protection of local traditions and ways of life when tourism expands in a globalized world! Languages are disappearing: according to UNESCO, more than a hundred disappear every year. Traditional crafts - and now industrial knowledge too - are lost. At the same time, some heritages are considered to be acquiring a rising value. Private actors develop operations that constitute heritages as private or public assets or institutions. New luxury groups such as the French LVMH (Louis Vuitton - Moët et Chandon - Henessy) and Kering (ex-PPR, PinaultPrintemps-Redoute) buy haute couture, ready-to-wear, luxury goods companies in order to exploit their reputation capital and put their know-how heritage to work. The value of trademarks, based on the reputation and image built up by a company, is now decisive in contractual arrangements and capital transactions.

To suggest an initial economic analysis of informal heritages we begin by considering the limitations of the standard economic analysis of heritages, which is biased towards official heritages (Point 2). Third, we suggest moving beyond these limitations by broadening the notion of heritages on the basis of specific economic and sociological analyses. Fourth, we apply this broadening to the study of the consequences of informal heritages on the economy and, fifth, on social life. The sixth point presents concluding remarks on informal heritages management issues. If it is true that informal heritages are at work in the economy and in social life as much as - and even more than - formal heritages, then it is high time economic analysis were extended to these new fields, in order to come up with new ways of managing informal heritages!

\section{WHEN CULTURE PRODUCES MANY DIFFERENT HERITAGES BUT ECONOMIC ANALYSIS FAVOURS OFFICIAL HERITAGES}

The economic analysis of cultural heritage has provided us with a lot of interesting results. Because it conceives of cultural heritage as a specific good, specific public management policies are implied (Benhamou, 2012; Greffe, 1990, 2003; Hutter and Rizzo, 1997; Rizzo and Towse, 2002; Rizzo and Throsby, 2006; Throsby, 1997). This has allowed the definition of coherent public policies for the management of cultural heritages. This analysis is, however biased towards defined and legitimated 'official' heritages, that is, cultural heritages managed by and for national and international public authorities, with a view to their preservation. UNESCO's first definition of cultural heritage reflects this bias: "Cultural heritage may be defined as the entire corpus of material signs - either artistic or symbolic - handed on by the past to each culture and, therefore, to the whole of humankind. As a constituent part of the affirmation and enrichment of cultural identities, as a legacy belonging to all humankind, the cultural heritage gives each particular place its recognizable features and is the storehouse of human experience. The preservation and the presentation of the cultural heritage are therefore a cornerstone of any cultural policy."1

Yet for twenty years, historians, sociologists, anthropologists and geographers (Graham, 2002; Graham and Howard, 2008; Harrison, 2012; Harvey, 2008; Smith, 2006; Tornqvist,

\footnotetext{
${ }^{1}$ Draft Medium Term Plan 1990-1995 (UNESCO, 25 C/4, 1989, p.57).
} 
1983) have been developing a growing body of analyses of material and cultural heritages, including both formal (e.g. UNESCO world heritage sites) and informal heritages (e.g. local languages). Firstly, they have shown that heritages often result not from any indisputable and intrinsic quality or specificity but out of strategies developed by nations ${ }^{2}$, groups and communities. Secondly, they analyse informal heritages that are capable of having as strong an impact as formal ones. Official heritages management may differ from that of informal heritages, yet the social and economic effects of heritages do not begin with their institutionalization. Moreover, formal heritages contain informal dimensions because they are encapsulated in specific cultures; their institutionalization and their use by social actors results from cultural debates, informal points of view and actor strategies. Informal heritages, then, include three types of heritage:

- Heritages that are informal prior to becoming institutionalized and formal

- Heritages that will remain informal, staying out of the perimeter and off the lists of official heritages

- Informal aspects of formal heritages

To widen the scope of heritage analysis and include informal examples, we use the word 'heritage' in a wider sense. Heritages include not just 'official' and 'institutional' heritages such as museums, libraries, archaeological and historic sites, archives, and so on, but also all heritages resulting from the accumulation and sedimentation of creativity, i.e. by the history that develops and passes culture through to society. This includes a whole range of elements from the heritage of know-how found in the Maison de couture to the recipes that are typical of a culinary culture, to a common language used within a territory. Individuals, families, companies, industries, territories, societies, and humanity - all inherit these resources from the past.

To economists, culture is an output for individual consumption and individual input, (through, for instance increasing individual knowledge and competences) but also as a collective consumption (visiting museums) and a collective input (culture being used to produce new culture). Moreover, some cultural goods, such as famous monuments or books, pass through time - and their value can even increase, as in the case of paintings. Some have spillover effects and appear as the sources of new utilities; these constitute cultural capital goods, cultural commons and cultural heritages.

The notion of heritages, when applied to collective items, refers to sets of elements, coming from the past, handed down from generation to generation, either on the basis of explicit and voluntary procedures or by tradition. In the first case, these are deliberately conserved in the present because they are considered to embody a specific value (cultural, economic or social) capable of producing amenities for the present and the future. In the second case, they contribute to social life and lastly as a result of a process of self-reproduction (which may turn into a process of dissolution). Even where they are informal, they result from a selection. Only some elements of the past pass through time. Those that do have a particular value, which justifies their transmission from generation to generation as well as their preservation.

This value is generally linked to a specific attribute, a particular quality (the indisputable beauty of the Mona Lisa or the Taj Mahal, the uniqueness of a site such as Macchu Pichu or the Grand Canyon) and/or a special significance for a specific community, contributing to its identity, as in the case of historic buildings (the Italian trulli) and cultural traditions (the French gastronomic meal or the traditional sericulture of Madagascar). Some

\footnotetext{
${ }^{2}$ China spent a great deal of money presenting UNESCO with new registration applications, and is now the third most represented country. The international organisation has publicly deplored the overrepresentation of some countries while others - mainly African countries - remain under-represented. Registration has a strong political impact, as well as strong incentive effects on tourism.
} 
material elements are considered heritage by communities even though they do not feature on any official lists: people living in a country may consider an old factory - in which a many of them worked for generations - to be their heritage and want to preserve it. To them, these elements are remarkable even if not in the sense of the UNESCO list. Moreover, immaterial heritage is not limited to the UNESCO list. Numerous 'practices, representations, expressions, knowledge, skills' (according to the UNESCO definition, Convention for the Safeguarding of the Intangible Cultural Heritage 2003, art. 2) exist around the world and have strong economic and social effects, and these do not wait for official recognition of heritages as being formal and remarkable before developing. For instance, for individuals and society alike, the first cultural heritage is obviously language. For a community this constitutes a common heritage that is the basis of social life, although it does not, as a rule, benefit from any protection.

Within heritages, cultural assets may be tangible (buildings, structures, cultural artefacts such paintings, sculptures, etc.) or intangible (ideas, practices, beliefs, values, traditions, and goods in the public domain, such as literature and music).

Some heritages remain informal and others become formal when they are involved in an institutional process of definition, delimitation and legitimation. These are generally governed according to particular procedures and by given organizations; for instance the Spanish government forbids the free export of Spanish paintings, whereas UNESCO protects world heritage monuments. Their legal status requires that everybody recognize them as heritages. This has had certain key consequences for the development of cultural heritages analysis.

Economic analysis favours official heritages because it was developed precisely to consider the public policies of organizations that are legally responsible of the protection of these heritages. It has been called upon to define coherent and efficient criteria in their management. Ever since the beginning of the history of heritage analysis there has been a close relationship between the public management of heritages and its analysis, in such a way that heritages are identified as public and explicit heritages.

The idea of remarkable monuments that express a specific quality and thus merit preservation -constituting a heritage of humanity- is an old one, as the traditional notion of the 'Seven Wonders of the World' attests to. The Renaissance movement provided a fresh opportunity to rediscover the origins of European culture, mainly the Greek and Roman arts, whose social value suddenly increased (Jokilehto, 1986). Political and religious reasons joined artistic ones, as the Old Roma became the symbol of Christianity and European civilization in establishing the identity (and, to them, the superiority) of Mediaeval and Modern Europe against invaders and Barbarians.

The development of nationalism in Europe was a fresh incentive to the restoration or conservation of the legacy of the past, and strengthened the identification of heritages with public heritage. The French Revolution 'invented' heritage (Choay, 1999) with its creation, in 1790, of the first organization (Commission des monuments historiques) to be charged with listing and preserving the 'national heritage' - mainly the monuments, paintings and sculptures that had been located in the castles and churches, henceforth the "collective property of the Nation". Later on, England, Germany, Italy and other countries established heritage policies. A lot of politicians believed that consideration of the past, coupled with the preservation of its surviving artefacts, to be a good way of reinforcing national consciousness at a time of fierce competition between European nations. Later on, international organizations decided to select and protect some heritages (for their exceptional quality) as elements of a common human heritage. This extension of heritages accelerated in the second half of the $20^{\text {th }}$ century, as 
international organizations (mainly $\mathrm{ICOMOS}^{3}$ and $\mathrm{UNESCO}^{1}$ ) broadened the scope of protected heritage: minor architecture, vernacular architecture, industrial architecture, urban fabric, sites, landscapes, environment, and lastly immaterial and cultural heritage - and today even virtual heritages such as websites, 3D animations and video games (Ahmad, 2006). Nevertheless, the debate concerned 'official' heritage and was conducted as though this 'official heritage' was indisputable. This is why the dominant economic analysis of heritages is still strictly linked to public policies regarding official heritages, which tends to limit the field of heritage analysis to the management of tangible and intangible assets belonging to administrative and official lists (the UNESCO lists of intangible cultural heritage and world heritage sites, museums governed by governmental agencies and so on); informal heritages are still crying out for a developed analysis.

\section{BEYOND THE LIMITATIONS OF STANDARD ANALYSIS OF CULTURAL HERITAGES}

In seeking to go beyond the limitations of standard analysis of cultural heritages, two distinct inputs demand consideration: some economists shed light on the key role played by informal heritages, whereas sociologists and political analysts discuss the official character of certain cultural heritages.

Some economists, outside of the standard field of economic analysis of the public management of official heritages, have highlighted the strong economic and social effects of informal heritages - even though they may not explicitly make use of the notion of heritage.

In the recent period, Douglass North has been one of the most important authors to focus on the legacy of the past and analyse its effects on path developments. He started out with a simple empirical observation: prior to colonization, South America and North America had eminently comparable levels of development, whereas today the difference between the two areas is considerable and continues to grow. Initial endowments in factors of production are unable to explain this, since both have significant and comparable resources. The difference could arise out of the incentive institutions provide to development. North showed how to distinguish between what we might call two heritages - one transmitted by England and the other by Spain and Portugal. English colonization imposed a horizontal and decentralized model - the market model - which multiplied incentives to seek profit through innovation and productivity. The Iberian colonization developed a second model - vertical and centralized based on rent-seeking and withdrawal from productive activities, which discouraged productive effort, increased transaction costs and weakened development. Moreover, heritages prevent efficient adaptation via a lock-in effect. In this way, North introduces the weight of history into economic analysis. Both colonizations created rules, behaviours, incentives and institutions, which passed through time and thus self-reinforced. Individuals were not aware of these heritages; their components seemed natural to them even though they were in fact social constructions transmitted through time - that is, heritages.

The Third Italy model (Bagnasco, 1977; Beccatini, 2004) is another important analysis focusing on the role of cultural heritage interpreted as a set of specific, individual, collective and social assets, allowing the development of cooperation and stimulation of innovation. In the Fifties and Sixties, falling transport costs and the extension of economies of scale encouraged most economists to envisage a world of very large companies of indifferent

\footnotetext{
${ }^{3}{ }^{3}$ Icomos $=$ International Council on Monuments and Sites; UNESCO = United Nations Educational, Scientific and Cultural Organisation.
} 
location. However, the outstanding success of the 'industrial districts', completely contradicted this expectation, and this success is now clearly related to cultural and social proximity, mainly relating to strong local heritages. Firstly, these districts set a common culture capable of lowering coordination costs: mutual trust, sharing of tacit knowledge, easy circulation of information, forms of cooperation in spite of competition, and so on. Secondly, they developed idiosyncratic effects, causing producers to benefit from the local specificities of resources, cultivated throughout history and the source of decisive comparative advantages. Again, we are confronted with a historical heritage - this time coming from the Middle Ages. This is an informal heritage - not recognized as such, but having powerful effects nonetheless.

Recent transitions from centralized economies to market economies have highlighted the importance of cultural institutions - one aspect of which is heritage. As Hayek stressed, the market is a social and cultural construction. Cultural heritages which are based on bureaucracy, contrasted with the culture of the market and the habitus of the homo oeconomicus (rational calculus, the search for profit opportunities, business morality, and compliance with enforced rules). This indicates that many (perhaps all) societies have heritages and are in some way dependent on these; heritages organize social life and constrain its development.

In doing this work, these economists have shown that the consequences of heritages are far wider than the consequences of legitimated heritages such as those listed by UNESCO. The necessity of taking informal heritages into consideration is reinforced by recent debates on formal heritage management - leading us to reconsider the distinction between formal and informal heritages by showing that public recognition of official heritages (and corresponding public management policies) fail to take all of their consequences into account.

Anthropologists, sociologists and experts in the analysis of cultural heritages have shown that official heritages have multiple informal dimensions and aspects. Far from being the natural results of the past, heritages result from social and cultural constructions. Some heritages are considered such by some individuals, groups and organizations but not by others, even where these are users: for many Madagascan silkworm breeders, their traditional and sophisticated know-how seems self-evident, and is not considered a heritage. Tunbridge and Ashworth defined heritage as 'a contemporary product shaped from history' (Tunbridge and Ashworth, 1996, p.20). It is a specific reading of the past underpinning the social, cultural and political identities of individuals, groups, places and states. Official heritages emerge, then, from a wider set (of heritages) that includes many informal heritages - some of which will become official while others will remain informal. The perimeter of heritage derives from cultural points of view: for example, industrial architecture and old industrial sites, formerly considered of no interest, can now be preserved because they represent an interesting sign of past times and social stories.

Secondly, once heritages become social and cultural constructions, conflicts arise in defining, delimiting and presenting them. Is the futurist Italian movement, which was sometimes close to fascism, worthy of flattery? What about Nazi and Stalinist architectures? How should we view all the symbols of colonial times, of Apartheid institutions and of slavery? Is the presence of the Soviet Union to be forgotten in the Baltic States, and how should we view the results of this presence? In other cases minorities and local people claim recognition of their specific identity - this is the case of Afro-Americans in the USA, Kanaks in New Caledonia and Aboriginals in Australia. Sometimes heritage is the direct object of appropriation conflicts: conflicts between Jews, Muslims and Christians about the Holy Places of Jerusalem; conflicts between people of Serbian, Croatian and Muslim origins about the Mostar bridge.

Heritage, then, rather than being a collection of things and sites, is a cultural process of meaning-making, a mentality, "a way of knowing and seeing" (Smith, 2006, p. 54): "Heritage, I want to suggest, is a cultural process that engages with acts of remembering that work to create ways to understand and engage with the present, and the sites themselves are cultural tools that 
can facilitate, but are not necessarily vital for this process" (Smith, 2006, p.44). The past is negotiated and reinterpreted; collective memories are collectively legitimized, sustaining the stability and the continuity of communities and helping bind groups or populations together. Since heritages define cultural, national and social identities (Crouch and Parker, 2003: 405), they are used to construct an identity and an associated memory - as shown by Jewish communities' struggle to develop the memory of the Holocaust. During the Second World War, Joan of Arc was simultaneously used as a symbol by the Resistance (to mobilise French people against the German Invaders) and by the Collaborationists (to criticize England), clearly demonstrating the dissonant character of heritage ${ }^{4}$. In recent times, the destruction of the Buddhas of Bamyian and of the old manuscripts conserved in the library of Timbuktu by an Islamist group further bears this out.

Beyond dissonance deriving from the multiple meanings that can be addressed by the subjects to the objects incorporated in a heritage, a growing source of dissonance is coming from the various contexts in which heritage is used. Heritage is at once both a cultural and an economic resource. With the commodification of heritages fast increasing, their supply seeks to match diverse - and sometimes conflicting - demands. As heritage becomes an economic commodity it encounters diverse demands driven by diverse motives. The case of touristic demands for heritages is enlightening. Are the people spending two days in the Angkor area interested in the same way as the archaeologists or the Buddhist priests? And does the Khmer heritage have the same meaning for tourists as it does for the inhabitants of Kampuchea? Development of the touristic use of local heritage can contaminate its intrinsic meaning - and in some cases, destroy or damage some of its material and immaterial components.

All these studies show that the consequences of formal and informal heritages are both very wide and potentially very complex. They may be direct (the utilities given by the visit to famous art galleries) or indirect (Lagerfeld designed a White Pierrot costume inspired by the famous painting of Watteau, kept in the Louvre museum), monetary (the effects of remarkable monuments or gastronomic heritage on tourist appeal) or non-monetary (the consequences of the disappearance of local languages on social life). This implies going beyond the standard economic analysis of the management of official heritages to cover every type of heritage and every aspect of these various heritages: official and non-official, formal and informal aspects. This type of analysis is still in its early stages, however, so we cannot claim to set out a general theory of informal heritages. In the next points, we do give some indications as to the results that can be achieved through an economic analysis of heritages that includes informal heritages.

\section{THE ECONOMIC EFFECTS OF INFORMAL HERITAGES}

Informal heritages and the informal aspects of formal and official heritages have economic effects - regardless of whether macro, meso or micro-analyses are concerned.

By producing over time, companies build heritages - specific resources that pass through time and can be used for new production. The case of the luxury industry (where such heritages are peculiarly important) is spectacular and justifies a resort to heritage analysis. Luxury companies create and produce on the basis of different heritages, using firstly a heritage of craftsmanship, handed down over generations of workers and providing them with the

\footnotetext{
4 "all heritage is someone's heritage and therefore logically not someone else's: the original meaning of an inheritance \{from which 'heritage' derives\} implies the existence of disinheritance and by extension any creation of heritage from the past disinherits someone completely or partially, actively or potentially. This disinheritance may be unintentional, temporary, of trivial importance, limited in its effects and concealed; or it may be long-term, widespread, intentional, important and obvious" (Tunbridge and Ashworth, 1996: 21, quoted by Smith: 80).
} 
technical skill to perform sophisticated operations arising out of a long succession of inventions and innovations. When Christian Lacroix opened his couture house in 1986 he needed highlyskilled workers and had to deal with highly-specialized workshops producing pearls, embroidery, buttons, trimmings, and handmade textiles (Laver 1995). The importance of craftsmanship heritage is attested to by the behaviour of leading luxury accessories suppliers such as Vuitton, Hermès, Gucci and Prada. They limit outsourcing, seeking to set up plants in places that are rich in highly-qualified labour. In the same way, analysis of industrial districts (Santagata 2010) has shown (in the case of the Italian districts, for instance) how the social heritage of craftsmanship has constituted a key condition for economic and social development. Luxury companies also use creative knowledge heritages. Such a heritage is private; the history of the Maisons de couture, the great designers (Chanel, Balenciaga, Dior, Saint Laurent) and the cult of creation represent a major incentive to creativity. This heritage develops both a 'stock and memory' and an 'experience' effect (apprenticeship from famous masters in the Maison or the Grand restaurant that facilitates the transmission of creativity, especially between generations). This takes the specific form of private heritages of creative products. In the fashion industry it constitutes both a physical stock of designs and models and the cultural heritage of a style (e.g. the Chanel style). When Lagerfeld became director of Chanel, his first decision was to spend a great deal of time visiting every Chanel Maison department, to immerse himself in its heritage. He sought to be inspired by (rather than to copy) the Chanel style in order to create a new Chanel in the style of Coco Chanel. This is extremely valuable, not just because it allows new designers to 'revisit' both old collections and styles and the history of fashion, but also because it allows customers to identify a style. Yet at the same time, there is a common heritage of creative knowledge - which also produces experience effects. Yves Saint Laurent was just 21 when he succeeded Christian Dior upon his death. His first collection - the Trapeze line - which was under the critical spotlight - demonstrated both a vast culture and the ability to fit into the rhythm of fashion. Creative heritage is also the ability to design new luxury goods, closely-related to haute couture, and thus to widen the product range. Old styles are the basis for new variations. Yesterday's fashion echoes the 1970s; tomorrow, it may echo the 1940 s, and so on.

In addition, companies accumulate reputation, creative and craft knowledge as well as patents. They develop an internal productive atmosphere, similar to the industrial atmosphere defined by Alfred Marshall (1890, 1919), but clearly related to these heritages - which constitute specific assets. Luxury groups such as LVMH and Kering and Richemont have, by taking over old Maisons de couture and luxury companies, become owners of the private heritages constituted by these companies. These heritages were hugely valuable and could provide a strong basis for the development of new luxury goods and the expansion of their markets. The industrial luxury groups value their semiotic heritage, in the form of the trademark. Bernard Arnault, the owner of LVMH, used to say that the source of the incredible success of Louis Vuitton is its 150-year history. Yet French luxury companies also benefit from common cultural heritages.

The French institutional heritage of Haute Couture and the Italian institutional heritage of Alta Moda include public policies aimed at improving art, fashion and creativity, trade associations, and more significantly, the institutional form of the Maison de haute couture, which occupies the key position - meaning that creativity also plays a key role. This boosts the incentive to creativity, in the fields of both production and management. They also use common cultural heritage as a background for creation. Sometimes, the influence of cultural heritage is very direct - as when Saint Laurent created his Mondrian collection, or when Watteau inspired Lagerfeld's famous White Pierrot costume.

Other industrial studies and case analyses also highlight the role of local, sectorial, and industrial heritages. These play an important productive role in the arts and in creative industries as fashion (Barrère et Santagata, 2005), wines, spirits and gastronomy (Barrère, 
Bonnard and Chossat, 2012), and even industrial production (Nieddu et Vivien, 2014). Heritages are stocks of past creativity, and can be used to develop new creativity.

Suppliers can also use common heritages related to an industrial or cultural cluster such as the Parisian fashion industry, the Italian Alta Moda and luxury craft industry or the Swiss watch-making tradition (Donzé, 2009). According to the Marshallian analysis of industrial districts, some places are able to develop a specific atmosphere that contributes to the expansion of spillover effects and to an increase in creativity. Reasoning within the framework of heritages can explain the origin and the reproduction of districts. The specific atmosphere constitutes a social and industrial heritage that is beneficial to many companies, and over time, those companies reproduce these competitive and lasting advantages.

The heritage approach leads to a new economic interpretation of the history of Champagne, explaining the exceptional success of this local industry. Instead of considering only the wine's monopoly position in terms of industrial economics and public choice analysis, the heritage approach focuses on the long historical process of the construction of an informal heritage by specific actors - the great Maisons de Champagne. This informal heritage explains this industry's specific organizational structure and regime as well as their relationship to economic performance through the management of this specific collective heritage (Barrère, 2007). Champagne was originally only a standard wine (until 1930 both the best and the worst wine could be found under the Champagne name) and included wine manufactured in Champagne using grapes grown in the South of France, Spain and even Algeria. The Champagne industry managed to transform Champagne wine into a luxury product by creating new institutions using the AOC (Appellation d'Origine Contrôlée - Protected Designation of Origin) system to impose high (and rising) quality across the whole industry. In this way, the great Maisons de Champagne built a sectorial heritage, related to a specific territory, constituted by a judicial and legal heritage (the AOC, trademarks, regulations and disciplines), through an economic heritage (land rents, production processes, marketing networks and corresponding profits) and through an institutional heritage (concerted management of some of the sector's problems). Both informal and formal components of this sectorial heritage framed behaviours (for instance, the search for a professional and collective agreement on grape prices) and institutions (the CIVC, Comité Interprofessionnel des Vins de Champagne, which brought winegrowers and merchants together to define the industry's collective management). The heritage approach also brings to light the territorial consequences of the management of Champagne (Barrère, Bonnard, Delaplace, 2014) - in particular the contradiction between a very successful activity (the Champagne wine) and a poor region (the Champagne region). The competition for sharing the rent, within the Champagne industry, leads to strategies that reduce spillovers and produce lock-in situations, rather than developing clusterization.

The role played by heritage in economic performance can be related to Veblen's analysis of productivity (Veblen 1990). For him, economic productivity mainly depends, not on the volume of material capital or equipment, but on a whole range of social relations and conditions, including social culture (Gagnon, 2007). Today, cultural heritages play an increasing role in the growth of a creative economy (Florida, 2002; Landry, 1995; Santagata, 2002; Zukin and Braslow, 2011). Just as a modern economy develops semiotic values and cultural goods based on creativity, heritages are used to increase supplier reputations and nourish creativity. In some parts of the creative industries, this role is even more decisive. Within creative industries, we have to distinguish between sectors using creativity that includes predominantly cumulative knowledge and those using creativity that includes predominantly non-cumulative knowledge. Science is the classic example of a field using creativity in the form of cumulative knowledge. Scientists use old scientific knowledge as input for the production of new knowledge that is more developed, more sophisticated, and more rigorous, so that over time, old knowledge melts into new knowledge, and ceases to have a value as such. On the other hand, non-cumulative products of creativity also exist. George Steiner noted that 
earlier works in art, literature and music are never superseded: "Chartres does not date... What ... is in advance on Homer or Sophocles, on Plato or Dante? Beyond Hamlet, what novel surpasses Madame Bovary or Moby Dick? “ (Steiner, 2001: 252). This means that the production of certain specific creative goods does not aim to improve knowledge and will not be replaced by better quality amenities in the future. Heritages are thus fungible in those fields governed by cumulative knowledge, whereas this is not the case in fields governed by noncumulative knowledge. And heritages included in both private and common cultural heritages have a strong value that sometimes increases over time.

\section{THE EFFECTS OF INFORMAL CULTURAL HERITAGES ON SOCIAL LIFE}

Cultural heritages play a strong role in both economic and social life - even though the majority remain informal, without public protection and without explicit management - as they are the main institutions that connect history, territory and society, defining the cultural context of social life. And, the more the economy becomes creative, the more the interpenetration between economic and non-economic cultural influences increases. Economic life is encapsulated in social life, and individuals are 'socialized individuals'.

T.H. Marshall (1950) has taken a particular interest in the relation between social heritage and social life. He analysed the socialization process by focusing on citizenship. For him, citizenship includes a social component in addition to its civil (rights necessary to individual freedom) and political (right to participate in the exercise of political power) components. This social component covers "the whole range from the rights to a modicum of economic welfare and security to the right to share to the full in the social heritage and to live the life of a civilized being according to the standards prevailing in the society" (op. cit., p. 149). The formal and informal components of the social heritage thus form the basis of the individual's social life as well as providing social cohesion.

French Solidarisme suggested a close, and more systematic, analysis. The Solidarist approach was developed by Célestin Bouglé (Bouglé, 1907) and Léon Bourgeois (Bourgeois, 1902), within Durkheim's institutionalist tradition (1893). This analysis used the idea of social interdependence between individuals to surpass the dichotomy between individualism and holism by considering socialized individuals, and defining society as a society of individuals (in the same way, cf. Elias, 1973). The Solidarists argue that every individual is born into a society that allows them to benefit from a social and cultural heritage: language, education, institutions and many other aspects that allow each personality to develop. Without their relation to society, no-one would survive. Social time is, then, longer than individual time. People benefit from this social and cultural heritage and, in return, they participate in its preservation, evolution and enlargement.

This framework can be read in economic terms. A society produces goods and institutions; yet most of the goods disappear in consumption (both unproductive and productive). Some - both material and immaterial - remain, and, together with institutions, these constitute a social and cultural heritage. Obviously, the stock of material capital (equipment, machines, buildings, etc.) is an important part of this social heritage. Yet rules, institutions, mentalities, and creative goods (artistic products, knowledge, and so on) are another important part of the heritage. These generally remain informal - but they have strong effects, simultaneously, on both consumption and production, and are both input and output, as well as closely connected with the conditions of the economic life of present-day society. Since individuals and groups use present inputs to produce their output - and also thanks to such institutions and common resources - it may be that social wealth depends as much on social heritage as it does on present choices and the individual resources of economic agents. 
Conversely, society has to manage this heritage (as well as the natural heritage) for future generations.

The development of the creative industries (and beyond these, the evolution from industrial to creative society) reinforces the scope of these observations. The approach of creativity challenges the paradigm of the industrial production of $19^{\text {th }}$ and $20^{\text {th }}$ centuries - a paradigm of energetistic production - which was common to the classical-Marxian and the Walrasian approaches. According to this one, wealth is an accumulation of commodities, goods produced by exploiting natural resources with direct and indirect labour but always with reproducible labour. Given the stock of natural resources, producing just needs spending labour (for Ricardo and Marx) or spending money to pay the inputs (for Walras). Production is transformation of energy (human or natural) in a commodity, according to the great energetistic logic of the relation between men and nature, developed in these centuries. "Rare" goods, that is to say, goods that cannot be reproduce with human labour, are of secondary importance and thus disappear from the analysis, as they seem to disappear from the core of economy. Such a paradigm forbids to think creation as something different from a marginal operation, only related to artistic world but expelled from the world of "normal" production. In the area of creation, the standard economic tools do not explain anything: establishing a production function for Picasso paintings or Galliano dresses does not make any sense. On the contrary, the creativity paradigm allows us to understand the working of creative economies and societies, which use culture for producing and consuming, for communicating and cooperating, and for enjoying life. People are encapsulated in a given culture which results from a given history and includes some formal and, mainly, informal heritages.

On a second side, patrimonial inflation expresses the increasing search of individuals and communities for roots and links to the past. There is at once an increasing demand for heritages and an increasing role of heritages in economic and social life. This leads to recognition of the role of heritages, both formal and informal, rather than reducing them to commons.

The commons analysis began with the observation of the inefficiency of the free-access to common resources, according to the famous paper of Hardin, "The tragedy of the commons" (1968). So, it put into light the question of common resources. Following the Hardin's paper, privatization and state control have been used to manage the common-pools of natural resources rather than maintaining their open access. Nevertheless, the development of practices and analyses has revealed the limitations of quota politics (for instance, through the Maine's Lobster Fishery case, Wilson, 1997) and the possibility of anti-commons tragedy caused by the multiplication and partitioning of property rights (Heller, 1998, 2008). Ostrom (1990) clarified these matters by distinguishing between CPR (Common-Pool Resources) and open access, and analysing the different forms of common property as specific institutions that gave rise to complex ownership organization. Her study mainly concerned natural resource commons - but this framework was also used for cultural commons (Hess and Ostrom, 2003). In this case, since the use of cultural resources is generally non-rival, the problem is even more complex because the efficiency question is about producing and developing natural resources rather than avoiding waste and overuse (Madison, Frischmann and Strandburg, 2010).

The literature on cultural and creative commons is peculiarly interesting. Nevertheless its resource management approach remained embedded in the mainstream approach to efficiency (even if it does surpass the standard opposition between private and public goods), and extended towards the transaction approach, and did not developed an institutionalist approach that explicitly sets institutions in their time and space context, beyond their direct management of resources. This was clear in the naturalist - perhaps technical - presentation of commons as a fourth type of goods (high subtractability and difficult exclusion).

On the contrary, the heritage framework considers that heritages are not only cultural commons, as long as they have a structure, a logic, a coherence, as they result from a selection 
and a specific building, and are not only unstructured collection of resources. The case of gastronomy is enlightening.

The recipes of gastronomy are shared resources and collective creations, which have been passed on over time. Nevertheless a gastronomic commons is a specific kind of commons for four main reasons:

a) A gastronomic commons is related to the identity of one group, in relation to other groups, and expresses its specificity through a collective idiosyncrasy. Fischler (1993) mentions that in popular language people are often designated by the special food they are supposed to like: in France, the Italians are called "macaroni" and the British "rosbif", while in England the French are "frogs" or "frog eaters".

b) Generally, a gastronomic commons is not a collection of resources but is structured by norms: for instance, these norms define what must be eaten at feasts and ceremonies in relation to the ordinary consumption of food; they define luxury goods in relation to standard ones.

c) Gastronomic heritages result from a social and cultural building of local communities and societies. English cuisine is different from French and Italian cuisines; local and regional cuisines are also different. Their development paths are not the same. They pass through time, by a process of cultural transmission, for instance through the conservation of the guild traditions and the mother-daughter transmission within families. The concept of heritage underlines the historical dimension of culinary and gastronomic commons that determines their main characteristics.

\section{CONCLUDING REMARKS: FROM ANALYSIS OF INFORMAL HERITAGES TO THEIR MANAGEMENT}

Where informal heritages have direct economic effects on some actors' earnings, those actors try to develop specific procedures to manage them. They claim for protecting them. Let us consider the strange case of the Harley Davidson bike.

The unique sound made by a Harley Davidson results from the design of the 45-degree V-Twin cylinder engine; it creates a unique 'potato potato' sound. Honda also made a more powerful 45-degree V-Twin - but sales were poor because it didn't "sound like a Harley". Honda therefore regressed and in 1995, produced a similar single crank-pin design that sounded more like a Harley. This bike was called the Shadow American Classic Edition (ACE). In this way, Honda sought to profit from the identification of the Harley sound with the Harley myth, and thus to convince consumers that a Honda bike also carries a free spirit, a counterculture and an image of camaraderie. It borrowed the typicality of the Harley heritage. The case was so serious that Honda and Harley went to court, where Harley claimed a trademark on the sound. This also shows how informal heritages can be valuable.

Companies attempt to protect their informal heritages - particularly in terms of reputation - by transforming them into more formal ones. In the luxury fashion industry, reputation derives from the physical person of the creator - who is generally dead, as are Christian Dior and Coco Chanel. The present owners' problem lies in transferring the positive image of the great creators who founded their own Maisons to the name of the company. The task, then, is to move from the name of the fashion designer - the griffe (an association between the creative products and the name of the creator, a personal IPR (Intellectual Property Right) -towards the trademark (an association between the products and the company name - a market IPR). Such a transfer allows the value of the designer's name to be extended over time and space. The value outlives the grand couturier themselves, extending beyond a particular body of work to cover the whole product range (Barrère and Delabruyère, 2011). 
In some cases informal heritages are caught by new actors, far from their original creators. Companies compete to take control of traditional heritages nobody is entitled to: pharmaceuticals companies seek access to ancient Indian medicines, transforming them into new private patents.

The question of protection and management of informal heritage resources is different when many people benefit from them, even if those benefits are monetary. Free riding situations may occur: for instance, a community succeeds in building institutions to manage these informal heritages; the Champagne industry has collective management of the vineyard's reputation via inter-professional institutions that check both production conditions and wine distribution. Collective heritages relating to given territories are sometimes protected by the law concerning geographical origin: in 2006, when the European Union defined the new designations regime, 2,500 designations relating to wines and, outside the wine area, 405 PDO (Protected Designation of Origin, mainly for cheese) and 291 PGI (Protected Geographical Indication, mainly concerning meats, fruits and vegetables) were registered. This number is still rising - though it concerns only foodstuffs. One way of extending this type of management in the case of goods relating to specific territories and a specific history is the development of collective brands (Santagata, 2010).

Other collective heritages have no protection, however, and nobody has a clear entitlement to manage them. In the French and Italian fashion industries, the common heritage of craft and creative knowledge suffers from the absence of any economic management. Nobody is responsible for the reproduction of the heritage over time, and companies are able to operate as free riders. In many countries, the economic crisis has led to a contraction of the craft sector traditionally linked to the fashion industry and, as a result of the weakness of public policies, the loss of highly qualified skills.

Where informal heritages have fewer direct economic consequences yet still have indirect economic and social consequences, they remain public goods, freely accessible, unprotected and unpreserved. Generally, collective informal heritages are very short of management. This is the case of languages: according to UNESCO, by 2100 , more than half of the more than 7,000 languages spoken on Earth - many as yet unrecorded - may disappear, taking with them a wealth of knowledge about history, culture, natural environment, and the human brain. To avoid this cruel fate, some communities try to develop management institutions -such as the Francophonie organization, for example. Nevertheless, the general situation is bad. Informal cultural heritages often offer better social value than formal ones, and the existence of these is a pre-condition for the use of formal heritages to build social wealth and happiness. Local and national authorities, as well as international organizations have to contribute to their management. We are only at the beginning of the road leading to this goal. It is a challenging path, since the problems of dissonance and competition - already studied in terms of official heritages - are also present here. Are local idioms useful for collective happiness? Or is it better to select only the main languages, and which of those? Should we insert the Christian tradition into the European heritage? Would the new European legal system be organized on the basis of English common law or continental civil law?

Moreover, the management of informal heritages cannot be limited to their preservation - because they may induce negative consequences. North underlined the ill-effects of the Iberian colonization model. Santagata (2010) focused attention on the risks of cultural policies favouring the conservation of heritages (both formal and informal) and of 'old' culture to the detriment of creation and 'new' culture. Private actors may also prefer exploiting heritages, and being rent-exploiters rather than innovating and risk-taking. In the case of gastronomy (Barrère, Bonnard, Chossat, 2012) gastronomic heritages provide competitive advantages yet may build obstacles insofar as far as development is concerned, by institutionalizing given practices and tastes, and thus creating barriers to change. The management of informal heritages is a highly complex yet urgent issue, and calls for new and strong developments in the economic analysis of both formal and informal heritages. 


\section{REFERENCES}

Ahmad Y. (2006) The Scope and Definitions of Heritage: From Tangible to Intangible, International Journal of Heritage Studies Vol. 12, No. 3, May 2006, pp. 292-300.

Bagnasco A. (1977) Tre Italie. La problematica territoriale dello sviluppo economico italiano. Il Mulino, Bologna.

Barrère C. (2007) The genesis, evolution and crisis of an institution: the protected designation of origin in wine markets. Journal of Institutional Economics. 2007, 3:2, 165-181.

Barrère C. and S. Delabruyère (2011) Intellectual property rights on creativity and heritage : the case of fashion industry, European Journal of Law and Economics, 2011, vol. 32, 3/305339.

Barrère C. et Santagata W. (2005) La mode, une économie de la créativité et du patrimoine à l'heure du marché, La Documentation Française, 2005.

Barrère C., Q. Bonnard and V. Chossat (2012) Food, gastronomy and cultural commons in Cultural commons, A new perspective on the production and evolution of cultures, ed. By E. Bertacchini, G. Bravo, M. Marrelli and W. Santagata, Cheltenham, Edward Elgar, pp. 129-150.

Barrère C., Q. Bonnard et M. Delaplace (2014) Valorisation des patrimoines et dynamique régionale : quelques enseignements à partir du cas du champagne. Territoire en mouvement. Revue de géographie et d'aménagement. 21(2014). http://tem.revues.org/2278.

Becattini G. (1998) Distretti industriali e made in Italy. Le basi socioculturali del nostro sviluppo economico. Bollati Boringhieri, Torino.

Benhamou F. (2012) Économie du patrimoine culturel, Paris, La Découverte, coll. « Repères / Culture et communication $», 126 \mathrm{p}$.

Bouglé C. (1907) Le solidarisme, Giard et Brière.

Bourgeois L. (1902) Solidarité, nouvelle édition 1996, Toulouse, Presses du Septentrion.

Choay F. (1999) L'allégorie du patrimoine, Le Seuil, Paris.

Crouch D. and G. Parker (2003) 'Digging-up' Utopia? Space, practice and land use heritage. Geoforum, vol. 34, n³, August 2003: 395-408.

Donzé P.Y. (2009) Histoire de l'industrie horlogère suisse : de Jacques David à Nicolas Hayek (1850-2000). Neuchâtel: Editions Alphil, Presses universitaires suisses.

Durkheim E. (1893) De la division du travail social, Paris PUF.

Elias N. (1973) La civilisation des mours. Paris: Calmann-Lévy.

Fischler, C. (1993) L'homnivore. Paris : O. Jacob.

Florida R. (2002) The Rise of the Creative Class. And How It's Transforming Work, Leisure and Everyday Life. Basic Books, New York.

Gagnon M.A. (2007) Capital, power and knowledge according to Thorstein Veblen: Reinterpreting the knowledge-based economy, Journal of Economic Issues, vol. 41, n², p. 593-600. 
Graham B. (2002) Heritage as knowledge: Capital or Culture? Urban Studies, vol.39, n 5-6, 1003-1017.

Graham B., Howard P. (edt. by) (2008) The Ashgate Research Companion to Heritage and Identity. Ashgate Publishing, Farnham.

Greffe, X. (1990) La valeur économique du patrimoine: la demande et l'offre de monuments, Anthropos-Economica, Paris.

Greffe X. (2003) La valorisation économique du patrimoine, Ministère de la culture; Département des Etudes de la Prospective et des Statistiques (DEPS), Paris.

Hardin G. (1968) The Tragedy of the Commons, Science 162 (1968) : 1243-48. 1, Issue 3, 2009, pages 243-253

Harrison R. (2012) Heritage: Critical Approaches. Routledge, London.

Harvey D.C. (2008) The History of Heritage, chapter 1 of the Ashgate Research Companion on Heritage and Identity : 19-36.

Heinich N. (2009) La fabrique du patrimoine, Editions de la Maison des Sciences de l'Homme, Paris.

Heller M. (1998) The Tragedy of the Anticommons, Harvard Law Review 1998/1.

Heller M. (2008) The Gridlock Economy: How Too Much Ownership Wrecks Markets, Stops Innovation, and Costs Lives. Basik Books. 2008.

Hess C. and E. Ostrom (2003) Ideas, Artifacts, and Facilities : Information as a Common-Pool Resource, Law and Contemporary problems, vol. 66: 111-145.

Hutter M. and I. Rizzo (1997) Economic Perspectives on Cultural Heritage, London: Macmillan.

Jeudy P.H. (1990) (ed.). Patrimoines en folie. Ministère de la Culture et de la Communication. Editions de la Maison des Sciences de l'Homme, Paris.

Jokilehto J. (1986) A History of Architectural Conservation, The Contribution of English, French, German and Italian Thought towards an International Approach to the Conservation of Cultural Property. DPhil Dissertation, University of York.

Landry C. (1995) The Creative City: A Toolkit for Urban Innovators Routledge.

Laver J. (1995) A Concise History of Costume. Thames and Hudson, London.

Madison M. J., B. M. Frischmann, and K. J. Strandburg (2010) "Constructing Cultural Commons in the Cultural Environment". Cornell Law Review, Vol. 95: 657-710.

Marshall A. (1890) Principles of economics, Macmillan, London.

Marshall A. (1919) Industry and trade, Macmillan, London.

Marshall T.H. (1950) Citizenship and Social Class and Other Essays, Cambridge University Press.

Ministère des Affaires étrangères et européennes (2009) Rapport Industries culturelles et Ministère des affaires étrangères et européennes. www.diplomatie.gouv.fr/.../091005. Accessed 14 June 2012.

Nieddu M. et F.D. Vivien (2014) Quels apports de l'approche patrimoniale pour l'analyse des transitions vers le développement soutenable : l'exemple de la chimie verte, in Economie appliquée, Tome LXVII, nº4, déc. 2014, p.40-70.

North D. (1991) Institutions, Institutional Change and Economic Performance, Cambridge : Cambridge University Press. 
Ostrom E. (1990) Governing the Commons: The Evolution of Institutions for Collective Action. Cambridge University Press.

Peckham R.S. (2003) Rethinking Heritage, Culture and Politics in Europe, London: I.B. Tauris.

Portney K.E. (2003) Taking Sustainable Cities Seriously: Economic development, the Environment and Quality of Life in American Cities, Cambridge: The MIT Press

Rizzo I. and A. Mignosa (2013) Handbook On The Economics Of Cultural Heritage, Edward Elgar, Cheltenham.

Rizzo I. and D. Throsby (2006) Cultural Heritage: Economic Analysis and Public Policy, in V.A. Ginsburgh \& D. Throsby (ed.), Handbook of the Economics of Art and Culture, Elsevier.

Rizzo I. and R. Towse (2002) The economics of heritage. A study in the political economy of culture in Sicily. Cheltenham, UK and Northampton, MA, USA, Edward Elgar.

Santagata W. (2002) Cultural districts, property rights and sustainable economic growth. International Journal of Urban and Regional Research, vol. 26, Issue 1, March 2002, pp. 9-23.

Santagata W. (2010) The Culture Factory. Creativity and the Production of Culture. Springer

Smith L. (2006) The uses of heritage, London et New York, Routledge.

Smith L. and N. Akagawa (2008) Intangible Heritages, Routledge.

Steiner G. (2001) Grammars of Creation, London, Faber and Faber.

Tornqvist G. (1983) Creativity and the renewal of regional life; in A. Buttimer (ed.) Creativity and Context: A Seminar Report, 91-112, Lund Studies in Geography. B. Human Geography, №50 Lund: Gleerup.

Throsby D. (1997) Seven questions in the economics of cultural heritage, in M. Hutter and I. Rizzo, Economics perspectives on cultural heritages, London, Macmillan, pp. 13-30.

Tunbridge J.E. and Ashworth G.J. (1996) Dissonant Heritage : the management of the past as a resource in conflict. Wiley.

Veblen T. (1990) [first edition, 1915], Imperial Germany and the Industrial Revolution, Transaction Publishers, New Brunswick, NJ.

Wilson J.A (1997) Maine's Lobster Fishery. Managing a Common Property Resource, 1997, Internet.

Zukin S., Braslow L. (2011) City, Culture and Society, Elsevier 


\footnotetext{
${ }^{1}$ Icomos = International Council on Monuments and Sites; UNESCO = United Nations Educational, Scientific and Cultural Organisation.
} 